\title{
COMPARATIVE FEDERALISM WITH REFERENCE TO CONSTITUTIONAL MACHINERY FAILURE (EMERGENCY) IN INDIA AND PAKISTAN
}

\author{
PANCH RISHI DEV SHARMA, \\ University of Lucknow (Lucknow, India)
}

DOI: 10.21684/2412-2343-2017-4-2-71-94

The constitutions and courts both in India and in Pakistan have shown their aspirations and fundamental faith in the federal structure but in practice there is a strong centripetal bias in each of their constitutional-political structures. This bias becomes more evident when the constitution sanctions power to the centre to proclaim emergency situations in the provinces on the basis of Constitutional Machinery Failure. Emerging from their colonial roots, the constitutions of India and Pakistan contain an identical provision on Constitutional Machinery Failure Emergency which has been misused and abused regularly and has been the biggest question mark on federal claims of the two States. This unique system of Constitutional Machinery Failure Emergency has also gone through a number of radical changes in India and Pakistan, which often have been influenced by each other. The article specifies the socio-political-constitutional background of Constitutional Machinery Failure resulting in Provincial Emergency, both in India and in Pakistan, their respective use and abuse by the Executive, legislative attempts to amend and control such power, and judicial response, with similarities and differences in respect of justifiability of such Emergency Proclamations.

Keywords: India and Pakistan; comparative federalism; Constitutional Failure Emergency Model; Constitutional Machinery Failure Emergency; defunct federalism; defunct democracy.

Recommended citation: Panch Rishi Dev Sharma, Comparative Federalism with Reference to Constitutional Machinery Failure (Emergency) in India and Pakistan, 4(2) BRICS Law Journal 71-94 (2017). 


\section{Table of Contents}

Introduction

1. Federalism and Comparative Law Jurisprudence

1.1. Methodology of Comparative Law

1.2. Methodology of Comparative Federalism

2. Federalism and Constitutional Emergency Model

2.1. Pre-Independence India: Emergency Model under the Government of India Act 1935: A Colonial Instrument to Suppress Shared Power

2.2. Constitution-Making Process in India and Pakistan and Development of Emergency Model in India and Pakistan, 1950 Onwards

2.2.1. Pakistan's Struggle for a Constitution and Constitutionalism 1956, 1962 and 1972-1973

2.2.2 Rule of Colonial Instrument (GolA 1935) as Interim Constitution in Pakistan to Suppress Federalism

2.2.3. The Constitution of Pakistan 1956: A Failed Attempt of Federalism

2.2.4. The Constitution of Pakistan 1962: Federalism Only in Words Not in Actions

2.2.5. The Constitution of Pakistan 1972: A Hope of Federalism by Redefining Constitutional Failure Emergency Model in Pakistan

2.2.6. Eighteenth Amendment to the Constitution of Pakistan 2010:

A Symbol of Real Change in Constitutional Failure Emergency Model and Federalism in Pakistan

2.3. Constitution of India 1950 and Influence of Government of India Act 1935

2.3.1. Emergency Model Secs. 45 and 93 (GolA 1935) Paved the Way for Arts. 355 and 356 of the Constitution

2.3.2. Constitution-Building Process and Debates on Constitutional Failure Emergency Model in India

2.3.3. Principle and Application of Constitutional Failure Emergency Model in India from 1950 to 2016

3. Judicial Approach in Pakistan and India to Redefine Constitutional Emergency Model and Application in the Light of Shared Power

3.1. The Supreme Court of Pakistan: A Courageous Interpretation of Constitutional Emergency Model and Federalism 1956 to 2010 3.2. The Supreme Court of India: Redefining Constitutional Failure Emergency Model and Federalism in India 1950 to 2016 4. Lessons from Comparative Federalism with Reference to Constitutional Machinery Failure (Emergency) in India and Pakistan

5. Reasons and Suggestions 


\section{Introduction}

Federalism in South Asia and particularly in India and Pakistan has a different and distinct history because of the efficiency and implementation of their federal plans and democratisation level. The difference in the federal design of the two countries is visible in their constitutional and federal polity. The difference can be measured by the degree of consociation within the federal plans proposed before independence, the constitutions created after independence and their performance.

\section{Federalism and Comparative Law Jurisprudence}

\subsection{Methodology of Comparative Law}

Comparative constitutional and political jurisprudence contains groundbreaking insights. J.S. Mill introduced the "method of difference" strategy for "controlled comparisons" in two political systems with a similar background and comparative independent variables. ${ }^{1}$ In this article, Constitutional Machinery Failure in both countries, India and Pakistan, has been compared as an independent variable with reference to their federal constitutional structures. Several comparative federal and political studies of South Asia, particularly of India and Pakistan, exist, ${ }^{2}$ and they provide in-depth background for the development of this article, but in respect of "President's rule" or Constitutional Machinery Failure in India and Pakistan there is a scarcity of comprehensive studies. ${ }^{3}$ This article specifies the socio-political-

John S. Mill, A System of Logic Ratiocinative and Inductive: Being a Connected View of the Principles of Evidence and the Method of Scientific Investigation. Vol. $1205-206\left(9^{\text {th }}\right.$ ed., London: Longmans, Green, Reader, and Dyer, 1875); John McGarry \& Brendan O'Leary, Introduction: The Macro-Political Regulation of Ethnic Conflict in The Politics of Ethnic Conflict Regulation: Case Studies of Protracted Ethnic Conflicts 1-40 (J. McGarry \& B. O'Leary (eds.), London and New York: Routledge, 1993).

Mill has recommended two strategies for controlled comparisons between two political structures: Method of Difference versus Method of Agreement. He recommends the Method of Difference approach is best suited for political structures with a very similar if not identical background and an independent variable is compared which makes the difference between political structures of identical background. The Method of Agreement approach is best suited for political structures of diverse backgrounds with a similar independent variable. In the case of the federal political structures of India and Pakistan, they both share similar if not identical backgrounds but the federal polity has changed drastically in comparison to each other. If summarized in terms of the constitution, the provisions and impact of constitutional emergency or presidential rule provisions plays a vital role in the development of their diverse federal polity.

2 Ayesha Jalal, Democracy and Authoritarianism in South Asia: A Comparative and Historical Perspective Ch. 1 (Lahore: Pakistan Sang-e-Meel Publications, 1995); Ayesha Jalal, The Struggle for Pakistan: A Muslim Homeland and Global Politics (Cambridge: Belknap Press of Harvard University Press, 2014).

3 Imtiaz Omar, Emergency Powers and Courts in India and Pakistan 23-79 (Leiden, Boston: Martinus Nijhoff Publishers, 2002); Katharine S. Adeney, Federal Formation and Consociational Stablisation: The Politics of National Identity Articulation and Ethnic Regulation in India and Pakistan, PhD thesis, The London School of Economics and Political Science (LSE) (2003), at 164 (May 10, 2017), available at http://etheses. Ise.ac.uk/428/; Mahendra Pal Singh, Comparative Constitutional Law in Comparative Constitutional Law: Festschrift in honour of Professor P.K. Tripathi 178-211 (M.P. Singh (ed.), $2^{\text {nd }}$ ed., Lucknow: Eastern 
constitutional background of Constitutional Machinery Failure resulting in Provincial Emergency, both in India and in Pakistan; their respective use and abuse by the Executive; legislative attempts to amend and control such power and the judicial response, with similarities and differences in respect of the justifiability of such Emergency Proclamations.

\subsection{Methodology of Comparative Federalism}

Federalism is the division of powers between two territorial units, for example centre and provinces, which includes at least two defined sets of government, independent in their own spheres from each other. In this division of power there should be no interference between the units, but there should be enough scope for co-operation between them. Such "co-operative non-interference" can be ensured by a written constitution to be interpreted by an independent judiciary. Academically, federalism is a matter of debate and serious discussion. According to political scientists and legalists, "federalism is the merger of sovereignties." As per M. Vile, the division of sovereignties into forms of powers has been established in constitutions to ensure proper federalism. ${ }^{4} \mathrm{He}$ further classifies it into asymmetrical and symmetrical federalism, where the constitution of the former does not establish the complete merger of sovereignties and the division of power is strongly in the hands of the centre. Professor Wheare followed the same line of thought and looked upon the Constitution of India as quasi-federal. ${ }^{5}$ There is another chain of thought of McGarry and O'Leary that adopts a practical approach to federalism and considers "federalism as a means to manage rather than eliminate ethnic and geographical differences, as it is necessary to manage diversity such as consociationalism and multiculturalism with constitutionalism." Federalism is also a "normative and ideological concept", as Watts sees "Federalism as a broad genus of political organisation that is marked by the combination of Self-Rule and Shared-Rule."' This approach could be traced

Book Company, 2011); Swarna Rajagopalan, State and Notion of South Asia (Boulder: Lynne Rienner Publishers, 2001); Jai Prakash Sharma, Federal Systems in India and Pakistan: A Comparative Perspective 89-110 (Jaipur: Printwell, 1987).

${ }^{4}$ Maurice J.C. Vile, Federalism and Confederation: The Experience of the United States and the British Commonwealth in Political Cooperation in Divided Societies 216-228 (P. Rea (ed.), Dublin: Gill and Macmillan, 1982).

5 Kenneth C. Wheare, Federal Government (4 ${ }^{\text {th }}$ ed., London: Oxford University Press, 1963). Wheare's institutional design of federalism and America-centric definition of federalism: "Does a system of government embody predominantly a division of powers between general and regional authorities, each of which, in its own sphere, is coordinate with the others and independence of them? If so, that government is federal. It is not enough that the federal principle should be embodies predominantly in the written constitution of the country..." As per this definition only the USA, Canada, Switzerland and Australia could be classified as federations.

6 McGarry \& O'Leary 1993, at 1-40.

7 Ronald L. Watts, Contemporary Views on Federalism in Evaluating Federal Systems (B. De Villiers (ed.), Cape Town: Juta, 1994). 
in the self-rule movements of India and Pakistan and also is the foundation of their respective constitutional make-up. The analysis of federalism is also linked with the aspirational struggle for Self-Rule.

\section{Federalism and Constitutional Emergency Model}

Ferejohn and Pasquino developed two famous emergency models which detail distinct structural models for the exercise of emergency powers: the Executive Model and the Legislative Model. ${ }^{8}$ On the basis of the proclaiming authority of the emergency (i.e. the executive or the legislature), the classes of emergency powers permissible, the framed time period for the emergency, and the review and control of emergency powers, the two scholars determine whether the particular emergency is based on executive dominance or on legislative checks and balances. On the basis of this classification India and Pakistan both emphatically follow the Executive Model of emergency which is borrowed from colonial times. There is scholarly literature ${ }^{9}$ in political jurisprudence which lays down that any emergency and particularly constitutional failure emergency - has to be used as the "last resort" in a "time-bound framework" and should be checked and balanced by the legislature.

\subsection{Pre-Independence India: Emergency Model under the Government of India} Act 1935: A Colonial Instrument to Suppress Shared Power

India and Pakistan have inherited the emergency model from the same colonial source - the Government of India Act $1935^{10}$ (hereinafter - GolA 1935). The basic object of Emergency Provisions in GolA 1935 was to manage law and order in the colony and ensure effective administration of the British Raj, even at the cost of Indian lives. ${ }^{11}$ Federalism in India and Pakistan in respect of Constitutional Machinery Failure Emergency has to be traced from its historical colonial roots and their making

8 John Ferejohn \& Pasquale Pasquino, The Law of Exception: A Typology of Emergency Powers, 2(2) International Journal of Constitutional Law 210 (2004).

9 Giorgio Agamben, State of Expression 1-31 (Kelvin Attell (trans.), Chicago: University of Chicago Press, 2005); Carl Schmitt, Political Theology: Four Chapters on the Concept of Sovereignty 1-207 (George Schwab (trans.), Chicago: University of Chicago Press, 1965).

10 The Government of India Act 1935 (25 \& 26 Geo. 5 c. 42) was enacted by the British Parliament to regulate and control the government in British India in 1935. This Act was very comprehensive, comprising 321 sections and 10 schedules. This Act played a vital role in the development of the constitutions in India and Pakistan. This Act was the base on which India and Pakistan developed constitutions and constitutionalism.

11 Nasser Hussain, The Jurisprudence of Emergency: Colonialism and the Rule of Law (Ann Arbor: The University of Michigan Press, 2003); Rande W. Kostal, A Jurisprudence of Power: Victorian Empire and the Rule of Law (Oxford and New York: Oxford University Press, 2008). 
of a constitutional system. ${ }^{12}$ With the colonial roots of constitutions in both States the constitution-making bodies were entrusted with a vital responsibility to amend the nature of colonialism from the texture of governing laws and the constitution so that the alleged Constitutional Machinery Failure Emergency provision could co-exist with the newer format of "federal democratic republics of India and Pakistan."

\subsection{Constitution-Making Process in India and Pakistan and Development of Emergency Model in India and Pakistan, 1950 Onwards}

India and Pakistan have a shared history, they both gained independence from British Colonial Rule by the same Act - the Indian Independence Act 1947. ${ }^{3}$ Although the division of British India was along religious lines, ${ }^{14}$ the legislative history and legacy is shared by the two countries. Prior to independence, the governing constitutional document was GolA 1935 until both countries formulated their own constitutions through their respective constituent assemblies. India became a republic on January 26, 1950 after intensive work of the Constituent Assembly for almost three years (well compiled in the Constituent Assembly Debates ${ }^{15}$ ). The Indian constitution-making process was the cornerstone of India's polity and constitutionalism. ${ }^{16}$

12 Warped Federalism, DAWN, March 29, 2008 (May 13, 2017), available at http://www.dawn.com/ news/955152 ("From the days of the first Governor General, Warren Hastings, until 1937, the subcontinent was ruled as a unitary state by successive Governors General. On Fools' Day that year, the Government of India Act 1935 went into force, granting autonomy to the provinces of British India. What was given by one hand was taken away by the other in the very same statute. Section 45 empowered the Governor General to show his council of ministers the door and assume direct governance at the centre. Section 93 conferred similar power on governors of the provinces. In both cases, the pre-condition was an honest belief 'that a situation has arisen in which the government... (of the federation or of the province) ... cannot be carried on in accordance with the provisions of this act"').

13 The Indian Independence Act 1947 (1947 c. 30 (10 \& 11. Geo. 6)) was formulated and received assent on July 18, 1947. It is an Act of Parliament of the UK which parted two independent dominions, India and Pakistan, with several small territorial units, free to join any one of them or stay independent and sovereign.

14 Henry V. Hodson, The Great Divide (London: Hutchinson \& Co. Publisher Ltd., 1969); Maulana Abul Kalam Azad, India Wins Freedom (Stosius Inc/Advent Books Division, 1989); Vapal Pangunni Menon, The Transfer of Power in India (Calcutta: Orient Longmans, 1957) (for details of the events during and before the division of British India).

15 Constituent Assembly Debates: Official Report is an outstanding work compiling all the arguments and debates that took place in the entire process of constitution-making in India. Constituent Assembly Debates: Official Report was later published by the Parliament of India in 10 volumes in both Hindi and English.

16 Benegal Shiva Rao, The Framing of Indian Constitution: A Study (New Delhi: Indian Institute of Administration, 1968); Granville Austin, The Indian Constitution: Cornerstone of the Nation (Oxford: Clarendon Press, 1966). 
2.2.1. Pakistan's Struggle for a Constitution and Constitutionalism 1956, 1962 and 1972-1973

In contrast, due to political and social turmoil ${ }^{17}$ Pakistan confirmed its republican status in 1956. Pakistan has had two more constitutions, one in $1962^{18}$ and another in $1973^{19}$ as a result of abrogation of the Constitution of Pakistan 1956 and 1962. The present Constitution of Pakistan was adopted in 1972 and gives broad discretionary powers ${ }^{20}$ to the President of Pakistan, powers which even include the extra-ordinary power to dismiss the Prime Minister and National Assembly. Some of these arbitrary powers were curtailed by subsequent constitutional amendments to the Constitution of Pakistan 1972 by the $13^{\text {th }}$ Amendment $1997^{21}$ and the $18^{\text {th }}$ Amendment $2010 .^{22}$

The foundational promise behind the idea of Pakistan is federalism, ${ }^{23}$ but in reality Pakistan is still struggling to find its bedrock of federalism in the Pakistani polity because of the existence of various so-called "democratically autocratic" and "autocratically democratic" military and civil government rule. The climate in Pakistan has remained authoritarian and centripetal despite the apparent federal claims and aspirations of the first two constitutions of Pakistan (the 1956 and 1962 constitutions) in particular. Unlike India, Pakistan failed to devise the institutional arrangements of power-sharing and accommodate its diversity at different levels of the polity, ${ }^{24}$

17 Sir Ivor Jennings, Constitutional Problems in Pakistan (Cambridge: Cambridge University Press, 1957); Herbert Feldman, Constitution of Pakistan (Karachi: Oxford University Press, 1956) (for an account of the reasons for the Short-lived Constitution of Pakistan 1956).

18 The Constitution of Pakistan 1962 was a result of the abrogation of the Constitution of Pakistan 1956. Ghulam W. Chaudhary, Constitutional Development in Pakistan (Vancouver: Publications Centre, University of British Columbia, 1969) (for details of the abrogation of this Constitution of Pakistan 1956).

19 The Constitution of Pakistan 1973 as a result of the abrogation of the Constitution of Pakistan 1962. Mohammad Munir, Constitution of the Islamic Republic of Pakistan, being a commentary on the Constitution Pakistan, 1962 (Lahore: All Pakistan Legal Decisions, 1965) (for details of the abrogation of the Constitution of Pakistan 1962).

20 The Constitution (Eighth Amendment) Act 1985 (Act No. XVIII of 1985) was the major source of arbitrary powers of the executive, even to dissolve the National and Provincial Assemblies and Prime Minister. The changes were made in Arts. 48(2) and 58(2) of the Constitution, which were relied upon by the President in 1990 and 1993 to dissolve the National Assembly(ies) and Prime Minister(s), Benazir Bhutto and Nawaz Sharif, respectively. The Supreme Court of Pakistan examined the scope of these amended provisions in Khawaja Ahmad Tariq Rahim v. Federation of Pakistan and Others, PLD 1992 SC 646 and Muhammad Nawaz Sharif v. President of Pakistan, PLD 1993 SC 473.

21 Constitution (Thirteenth Amendment) Act 1997 (Act No. I of 1997), the statement and object of reasons for adopting it is as follows: "In order to strengthen parliamentary democracy it has become necessary to restore some of the powers of the Prime Minister which were taken away by the Constitution (Eighth Amendment) Act 1985."

22 Constitution (Eighteenth Amendment) Act 2010 (Act No. X of 2010).

23 Muslim League's Resolution 1940 at Lahore, which promised that Pakistan shall be a federal state based on the principle of shared power.

24 Mahendra Prasad Singh \& Veena Kukreja, Federalism in South Asia 75-77 (Delhi: Routledge, 2014). 
which led to the disintegration of Pakistan and the creation of the new nation state Bangladesh in 1971. The Constitution of Pakistan 1972 accommodated provincial autonomy, but failed to provide equitable and sustainable power-sharing ${ }^{25}$ to reduce the "Punjabisation of Pakistan." ${ }^{26}$ No doubt in whatever form hints of federalism can be found in today's Pakistan, it is largely because of the Constitution of Pakistan 1972, which is why M. Waseem ${ }^{27}$ classified Pakistan into Pre-Federalisation (19471971) and Federalisation (1971 onwards).

\subsubsection{Rule of Colonial Instrument (GolA 1935) as Interim Constitution in Pakistan to} Suppress Federalism

Federalism and Constitutional Machinery Failure Emergency provision has an interesting development in Pakistan. At independence, Pakistan incorporated the Government of India Act 1935 as its interim constitution, thus sec. 45 automatically found its scope in the "asymmetrical federal polity" of Pakistan. In the constitutionmaking process, an identical provision to sec. 45 of GolA 1935 was also incorporated. Under this interim constitution, the centre maintained a dominant role over the provinces right from the beginning. The dismissal of the Khan Sahib Ministry in the North-West Frontier Province on August 22, 1947, M.A. Khuhro on April 20, 1948 in Sindh, Mamdoth's on January 25, 1949 and Fazl-ul-Haq's in 1954 in East Pakistan (under sec. 92-A of the 1935 Act), despite the fact each government enjoyed a majority in its Assembly, were a reflection of the federal principles the country was founded on; this led to a precedent which later on led the centre government to restore their reserve powers to dismiss provincial ministries. ${ }^{28}$ The rise of the military to power in October 1958, March 1969, July 1977 and October 1999 undermined the prospects of federalism and provincial autonomy. The military governments either abolished the prevailing constitutions (October 1958 and March 1969) or suspended them completely or partly (July 1997 and October 1999), collapsing the basis of federalism. Under military rule Pakistan became a totally centralised state, because military government was not subject to any Constitution and was supreme authority for both federal and provincial systems although the official sources continued to describe the country as a federal state.

25 Singh \& Kukreja 2014, at 112.

26 The constitutional and political arrangements in Pakistan have always favored the dominant ethnonational group "Punjabi," which has led to the term Punjabisation of Pakistan where the interests of smaller states are unheard and unaddressed in front of a bigger province like Punjab.

27 Mohammad Waseem, Federalism in Pakistan (August 2010) (May 10, 2017), available at http://www. forumfed.org/pubs/Waseem-Fed-Overview.pdf.

28 Zulfikar Khalid Maluka, The Myth of Constitutionalism in Pakistan 191 (Karachi and New York: Oxford University Press, 1995). 


\subsubsection{The Constitution of Pakistan 1956: A Failed Attempt of Federalism}

The Constitution of Pakistan 1956 was the first hope for constitutionally established federalism in Pakistan, but because of strongly centralised themes like "One Unit System" and "Parity Formula,"29 hope remained only in words. The Constitution of Pakistan 1956 proclaimed the Federal Islamic Republic of Pakistan under Art. 1, but actually the Constitution was based on GolA 1935 with firmer centripetal bias; in addition to the division of subjects in lists, provisions such as Art. 193 ensured arbitrary constitutional emergency powers to the Central Government. Other than that, the Central Government gained the power to make laws in matters of the State under Arts. 107, 108 and 191, and even administratively provinces were under strong domination from the centre (Arts. 125 and 126). Unlike Art. 45 of GolA 1935 and Art. 356 of the Constitution of India 1950, Art. 193 $3^{30}$ ensured that imposition of Constitutional Emergency could only be done on the "Receipt of Governor, if the President has [been] satisfied that the situation cannot be carried on in accordance with the provision of the Constitution."

\subsubsection{The Constitution of Pakistan 1962: Federalism Only in Words Not in Actions}

The Constitution of Pakistan 1962 referred to federalism in the Preamble, not in Art. 1 as the previous Constitution of 1956 had done. On the one hand, the Constitution of Pakistan envisaged the residuary power of law-making in the provinces, but it ensured that the provinces did not reach the position to use such powers. The Constitution was an attack on federalism as it made the presidentappointed Governors the heads of provincial governments and provided provisions such as Art. 131(2) by which the centre government may as per the national interest in respect of the security of Pakistan have overruling power to make and execute laws

29 The One Unit System was adopted in 1954, in which Pakistan was divided into two zones: East and West Pakistan, so that any voice raised for rights and autonomy from West Pakistan could be controlled with one stronger unit from East Pakistan, which was mainly Punjab followed by the smaller states. The One Unit System was also supplemented with the parity formula so that in the National Assembly of Pakistan, centralised superiority could be ensured.

30 Constitution of Pakistan 1956, Art. 193(1): If the President, on receipt of a report from the Governor of a Province, is satisfied that a situation has arisen in which the government of the Province cannot be carried on in accordance with the Provisions of the Constitution, the President may by Proclamation (a) assume to himself, or direct the Governor of the Province to assume on behalf of the President, all or any of the functions of the Government of the Province, and all or any of the powers vested in, or exercisable by, anybody or authority in the Province, other than the Provincial Legislature; (b) declare that the powers of the Provincial Legislature shall be exercisable by, or under the authority of, Parliament; (c) make such incidental and consequential provisions as appear to the President to be necessary or desirable for giving effect to the objects of the Proclamation, including provisions for suspending in whole or in part the operation of any provisions of the Constitution relating to anybody or authority in the Province: Provided that nothing in this Article shall authorize the President to assume to himself, or direct the Governor of the Province to assume on his behalf, any of the powers vested in, or exercisable by, a High Court, or to suspend either in whole or in part the operation of any provisions of the Constitution, relating to High Courts. 
in matters of the provinces too. Interestingly, the second Constitution of Pakistan 1962, under Art. 74, ${ }^{31}$ provided wide-ranging powers to the provincial Governor to dissolve the Provincial Assembly; such dissolution could take place even in matters of differences between the Governor and the Assembly, the only requirement for this was assent from the National Conference and the President's concurrence. Art. 30 of the Constitution of Pakistan 1962 widened the Emergency Proclamation provisions, which included any imminent danger that threatened the security of Pakistan, because of war or external aggression, while in respect of the provinces emergency could be declared on the basis of security or economic life having been threatened by internal disturbance beyond the power of a provincial government to control. Thus, with the joint impact of Arts. $30^{32}$ and 74 the Provincial Assembly could be dissolved if there was conflict between the Governor and the Provincial Legislative Assembly, decided in favour of the Governor by the National Conference, approved by the President and in regard to internal disturbance beyond the control of the provincial system.

\subsubsection{The Constitution of Pakistan 1972: A Hope of Federalism by Redefining} Constitutional Failure Emergency Model in Pakistan

The natural growth of the Constitution of Pakistan 1973 was hampered by two military takeovers, in July 1977 and October 1999. These coups strengthened centralisation and hindered the evolution of the Constitution to respond to the changing political, economic and developmental demands of the provinces. The Constitution of Pakistan 1972 did not contain a Provincial List; it contained the Federal List of 67 subjects and the Concurrent List of 47 subjects. Part X of the Constitution of Pakistan 1972 made special mention to "Emergency Provisions" in six broad articles, Arts. 232 to 237; wherein Art. 234 specifically mentions, "Power to issue proclamation in case of failure of Constitutional Machinery in a province," which details the procedure as:

(1) If the President, on the receipt of a report from the Governor of a Province is satisfied that a situation has arisen in which the Government of the Province cannot be carried on in accordance with the provisions of the Constitution, the President may, or if a resolution in this behalf is passed

31 Constitution of Pakistan 1962, Art 74: Where a conflict on a matter has arisen between the Governor of Province and the Assembly of the Provinces; the conflict has been referred to the National Assembly in accordance with this Article for decision, the National assembly has decided the conflict in favor of the Governor; and the President has concurred in the dissolution of the Provincial Assembly by the Governor may dissolve the Assembly of the Provinces.

32 Constitution of Pakistan 1962, Art. 30(1): If the President is satisfied that a grave emergency exists (a) in which Pakistan or any part thereof is in imminent danger by war or external aggression or (b) in which the security or economic life of Pakistan is threatened by internal disturbance beyond the power of provincial government to control, the President may issue a Proclamation of Emergency. 
by the each house separately shall, by proclamation (a) assume to himself or direct Governor to assume on his behalf all or any of the functions of the Government of the province.... ${ }^{33}$

Though the most damaging features of the amendment were done away with by the $13^{\text {th }}$ Amendment, they made a spectacular comeback in the $17^{\text {th }}$ Amendment, then again neutralised by the $18^{\text {th }}$ Amendment 2010 .

\subsubsection{Eighteenth Amendment to the Constitution of Pakistan 2010: A Symbol of Real} Change in Constitutional Failure Emergency Model and Federalism in Pakistan

The $18^{\text {th }}$ Amendment to the Constitution of Pakistan has been an astonishing change for the establishment of Self-Rule and Shared Rule. Some cardinal changes in favour of federalism brought about by the $18^{\text {th }}$ Amendment are reproduced as follows. The amendment increased the membership of the Senate, resulting in raising more voices for the provinces; presidential power to appoint the Governor was altered such that it could be done as per the aid and advice of the Prime Minister; Art. 144 added to the powers of the provincial legislatures which were now empowered to amend and repeal laws made by the Parliament which has legislated with the consent of one or more provincial assemblies - such a change is unprecedented in the history of federalism in South Asia, because the Constitution of India still does not empower the provincial legislatures to do likewise..$^{34}$ Additionally, the $18^{\text {th }}$ Amendment abolished the concurrent list and instituted the residuary power of law-making exclusively in the provinces, which is also unprecedented in South Asian federalism; ${ }^{35}$ it established the Council of Common Interests, the National Economic Council, the National Finance Council and vested the ownership of mineral and natural gas resources in the joint ownership of the province and the centre, again something that is unprecedented, and remarkable, all to establish the federal bedrock in Pakistan. In respect of constitutional emergencies, the $18^{\text {th }}$ Amendment, Constitution (Eighteenth Amendment) Act $2010^{36}$ provides Art. 234. The original Article in the 1972 Constitution used the phrase "on the receipt of a report from the Governor or otherwise," and the original Article also paved the way for the resolution

33 Syed Mujawar Hussain Shah, Federalism in Pakistan: Theory and Practice (Islamabad: Quaid-i-Azam University, 1994).

34 Constitution of India 1950, Art. 252: Power of Parliament to legislate for two or more states by consent and adoption of such legislation by any other state. Art. 252(2) further clarifies that any act so passed by the Parliament may be amended or repealed by an act of Parliament but shall not be, as respect any state to which is applies, be amended or repealed by an Act of the legislature of that state.

35 Unlike the Constitution of India 1950 which institutes the residuary powers of legislation exclusively in the Parliament, under Art. 248, "Parliament has exclusive power to make any law with respect to any matter not enumerated in the Concurrent List and State List." 
to be approved at the "joint sitting, ${ }^{\prime 37}$ replaced by the phrase "by each House."These changes are welcome, but provisions like Art. 234 in the name of Constitutional Emergency have been invariably used in Pakistan (as well as in India) as a weapon against the provinces, particularly those governed by parties opposed to the federal government. Subsequently, the $8^{\text {th }}$ Amendment to the Constitution 1972 empowered the President to dissolve the provincial (as well as federal) assemblies and governments on his own initiative. The enjoyment of the presidential right to dissolve the centre government (in 1988, 1990, 1993, 1996) under sec. 58-B ultimately dismissed all four provincial governments too, including the one that remained in opposition to the centre. Now the Emergency Proclamation cannot be introduced until and unless the Governor has recommended it, which requires the backing of a resolution by the provincial legislature and within ten days it has to be approved by both houses of the Parliament.

\subsection{Constitution of India 1950 and Influence of Government of India Act 1935}

Constitutional Machinery Failure Emergency in India is detailed under Art. 365 of the Constitution of India, which is reflective of the approach and intention of sec. 45 of GolA 1935 that provides a system for the Failure of Constitutional Machinery for the federation in Part II, Chapter V of the Act. Sec. 45 provided power to the Governor General to issue a proclamation, if satisfied that the situation had arisen in which the government of the federation could not be carried on in accordance with the provision of the Act. An identical provision existed in GolA 1935 regarding the government of the federation under sec. $93 .{ }^{38}$

2.3.1. Emergency Model Secs. 45 and 93 (GolA 1935) Paved the Way for Arts. 355 and 356 of the Constitution

It is to be noted that GolA 1935 was in reply to the demand by the Congress Party for constitutional reform and self-government in Imperial India, thus reasonable caution was maintained there, so that the demands of the Congress Party were met while keeping the interests of the British government well protected. Art. 12(1) of GolA 1935 is an example of such caution and protectionism in favour of imperialism the Governor General shall have special responsibility in "(a) the prevention of any grave menace to the peace or tranquillity of India or any part thereof."This section (12(1)) must be read along with sec. 102, which empowered the Governor General to make an Emergency Proclamation. The reasoning behind secs. 45, 93, 12(1) and 102 was to keep the Governor General at the apex and supreme authority, and no popularly elected government by any stretch of the imagination will have any say

37 Id. substituted by the words "by each House separately."

38 Sec. 93 of GolA 1935 was mutatis mutandis in which "Governor of Provinces" and "Government of Province" were substituted for "Governor General" and "Government of Federation," respectively. 
against the Governor General. In the form and in the name of constitutional reform such provisions actually made a mockery of the principle of responsible government and constitutionalism. Under sec. 45 the "satisfaction of the Governor General" was not justified, thus the grounds on which the Governor General's satisfaction was reached that the constitutional machinery had failed was unexplained by the Act. Similarly, although the chapter under which secs. 45 and 93 were instituted is titled "Provisions in the case of failure of Constitutional Machinery," the language under secs. 45 and 93 was as broad to include "that a situation has arisen in which the government of the federation cannot be carried on in accordance with the provisions of the Act." Even though the power under secs. 45 and 93 was so great and emergent in nature, it was never referred to as "Emergency Provision," rather it was referred to as "Provisions in the case of failure of Constitutional Machinery." Only sec. 102, in its marginal notes, referred to it as the "power of the Federal Legislature to legislate if an Emergency is proclaimed." Sec. 102 paved the way for Arts. 352 and 353 in the Constitution of India 1950, under the heading of "Emergency Provision," and rightly so secs. 45 and 93 paved the way for Arts. 355 and 356 under the same heading.

There is no doubt that such provisions are needed in any workable democratic structure and particularly when a democracy is embarking upon a federal structure through a constitutional set-up. But the correct drafting was needed when the transformation of secs. 45 and 93 into Art. 356 was taking place in the constitutionmaking process. First and foremost, what was needed was that if secs. 45 and 93 are transformed into Art. 356 as "Emergency Provision" and as "provision for failure of Constitutional Machinery," then the intentionally kept broad language and misinterpreted secs. 45 and 93 have to be kept within constitutional limits. The reasons for keeping almost the identical language in Art. 356 as was found in secs. 45 and 93 is beyond explanation. Secs. 45 and 93 were an intentional step by the imperial legislature to keep every element of the federal polity and responsible government under direct control and check by the Governor General. There is no space for such broad terms as "if satisfied" or "a situation has arisen in which the government of the federation cannot be carried on in accordance with the provisions of the Act." Such broad terms make federalism dilute itself and authoritarianism dominate to a large extent.

2.3.2. Constitution-Building Process and Debates on Constitutional Failure Emergency Model in India

The Draft Constitution of India ${ }^{39}$ was submitted to the President of the Constituent Assembly of India by Dr Ambedkar, with the changes that the Drafting Committee

39 Prepared by the Drafting Committee and published under the authority of the Constituent Assembly of India, 1948. 
thought desirable in the footnotes of the draft constitution. ${ }^{40}$ Arts. 277 and 278 in Part XIII of the draft constitution were titled "Emergency Provisions." Amazingly, and contrary to the letter of Dr Ambedkar, these articles were sidelined, but no footnote was there for the changes made by the Drafting Committee. Dr H.M. Seervai, in his valuable book Constitutional Law of India, ${ }^{41}$ has shown his amusement at the absence of any footnotes with these articles in the draft constitution.

\subsubsection{Principle and Application of Constitutional Failure Emergency Model in India} from 1950 to 2016

The Constitution of India 1950 prescribes the provision in case of failure of constitutional machinery in states under Art. 356, as per the article:"If the President, on the receipt from the Governor of a state or otherwise, is satisfied that a situation has arisen in which the government of the state cannot be carried on in accordance with the provision of the constitution, the President may by proclamation..."The provision is similar to the parent provision under sec. 93 of GolA 1935 and two prior provisions in the Constitution of Pakistan 1956 and 1962, unlike the Constitution of Pakistan 1972 (Art. 234). The language and application of Art. 356 in the Indian Constitution had always been debated and often criticised. The notorious $38^{\text {th }}$ Constitutional Amendment Act 1975 under the regime of Mrs Indira Gandhi had added clause (5) to Art. 356 which barred any form of judicial review, on any grounds, over an Emergency Proclamation. This arbitrary and unconstitutional provision was substituted and removed by the $44^{\text {th }}$ Constitutional Amendment Act 1978. Now judicial review of the proclamation would $\mathrm{lie}^{42}$ as held by the nine-judge decision of the Supreme Court on any grounds upon which an executive determination which is founded on "subjective satisfaction" can be questioned. This part is dealt with in detail in the next paragraphs. Other than that, Art. 257(1)(2)(3) empowers the Union Government to give directions to a state as therein provided non-observance of which would result in conceiving that the constitutional machinery has failed in the state, as per Art. 365. In this respect Art. 355 also places the duty on the Union to protect every state against external aggression and internal disturbance and to ensure that the government of every state is carried on in accordance with the provisions of the Constitution. This duty acts as a justification for exercising the

40 Dr Ambedkar submitted the Draft Constitution with a covering letter he wrote inter alia, "[T]here were however some matters in respect of which the Drafting Committee felt it necessary to suggest certain changes. All such changes have been indicated in the Draft by underlining or side-lining the relevant portions. Care has also been taken by the Drafting Committee to insert a footnote explaining the reasons for every such change." Draft Constitution of India, p. (iii).

${ }^{41}$ Hormasji Maneckji Seervai, Constitutional Law of India 3086-3089 (4 ${ }^{\text {th }}$ ed., New Delhi: Universal Publication House, 1991).

42 A.K. Roy v. Union of India, AIR 1982 SC 710; anything contrary said in State of Rajasthan v. Union of India, AIR 1977 SC 1361, is no longer good law; S.R. Bommai v. Union of India, 1994 (2) JT 215 [Sawant J, para. 187; Pradhan J, para. 2]. 
extra-ordinary centralised power under Art. 356, with yet to be concretely defined and open ended expressions, specifically used to empower the centre over the states.

\section{Judicial Approach in Pakistan and India to Redefine Constitutional Emergency Model and Application in the Light of Shared Power}

\subsection{The Supreme Court of Pakistan: A Courageous Interpretation of Cons- titutional Emergency Model and Federalism 1956 to 2010}

One of the most regressive provisions of the Constitution of Pakistan 1972 was to place Constitutional Emergency under Art. 236(2), ${ }^{43}$ which bars judicial review of the proclamation issued under Art. 234. In Pir Sabir Shah v. Federation of Pakistan and Others, ${ }^{44}$ the court interpreted Art. 236(2) with Art. 234 and observed that the constitutional bar on the judicial review of the proclamation will not cover the proclamation without jurisdiction, coram non judice or mala fide and superior courts will have jurisdiction to examine a proclamation from three jurisdictional aspects. Justice Saeeduzzaman Siddiqui while pronouncing the important judgment held the constitutional spirit above the man-made constitutional mandate. The judgment was reflective of the passionate words of Justice Fakhruddin G. Ebrahim in Niaz Ahmed Khan v. Province of Sind $h{ }^{45}$ while interpreting the rationality of judicial review in Pakistani Islamic Jurisprudence under Art. $227,{ }^{46}$ the "obligation to do justice to all at all times is the paramount duty and cardinal principle of Islam and to deprive courts of their functions to adjudicate upon complaints by its citizen against the State violated a fundamental concept of Islam." ${ }^{17}$

Pakistan's struggle for the establishment of a meaningful "federal democracy" with the "rule of law" and an "independent judiciary" has seen a chain of arbitrary Emergency Proclamations (by civilian as well as military Executives) of both national emergency and Constitutional Machinery Failure Emergency along with the suspension of the Constitution through military coup; but it has also seen the spirited reaction of the Pakistani citizenry, lawyers and the judiciary through several landmark judgments of the Supreme Court of Pakistan. The Supreme Court responded after

43 Constitution of Pakistan 1972, Art. 236(2): The validity of any proclamation issued or order made under this Part shall not be called in question in any Court.

44 PLD 1994 SC 738.

45 PLD 1977 Karachi 604.

46 Constitution of Pakistan, Art. 227: Provisions relating to the Holy Quran and Sunnah, (1) all existing laws shall be brought in conformity with the Injunctions of Islam as laid down in the Holy Quran and Sunnah... and no law shall be enacted which is repugnant to such injunctions.

47 Supra note 45 , at 669-670. 
the radical judgment of legitimising a military coup in State $v$. Dosso ${ }^{48}$ later reversed in Asma Jilani v. the Government of Punjab, ${ }^{49}$ where the Court mandated "limited condonation of the acts of usurper" while considering the legitimation of the military coup. Finally, in Begum Nusrat Bhutto v. Chief of Army Staff ${ }^{\circ}$ there arrived the spirited response from the Supreme Court of Pakistan in a cautious application of the doctrine of necessity to acts of martial law by the regime which put in abeyance the provisions of the Constitution of $1972 .^{51}$

In another leading judgment, Mian Manzoor Ahmad Wattoo v. Federation of Pakistan and Others, ${ }^{52}$ Justice Malik Muhammad Qayyum pronounced the ideal for Pakistani federalism in the context of the Constitutional Machinery Failure Emergency. His impactful words in the majority opinion:

Article 1 of the Constitution admits Pakistan is an Islamic Republic having federal character... and in such a system federation the division of power between the federation and its units must yield to supreme interest of unity and solidarity of the federation, federation must possess necessary power to intervene but this power in any way must not destroy the equilibrium between federation and federating units and their autonomy. ${ }^{53}$

Justice Malik Muhammad Qayyum referred to several illustrations of Albert Venn Dicey's An Introduction to the Study of the Law of Constitution ${ }^{54}$ and notable Pakistani constitutionalist A.K. Brohi's Fundamental Law of Pakistan ${ }^{55}$ to determine that the State should be cautious when invoking Art. 234, as it is an exception and emergency mechanism. Justice Qayyum strongly observed that:

[O]n the language of Article 234 it is apparent that the power granted to the President under Article 234 is not unbridled and uncontrolled, firstly it can be reviewed that the President may be satisfied and secondly that the satisfaction

\footnotetext{
48 PLD 1958 SC 533.

49 PLD 1972 SC 139.

50 PLD 1977 SC 657.

51 Upendra Baxi, Constitutional Interpretation and State Formative Practices in Pakistan: A Preliminary Exploration in Comparative Constitutional Law: Festschrift in honour of Professor P.K. Tripathi Ch. IX, 202-205 (M.P. Singh (ed.), $2^{\text {nd }}$ ed., Lucknow: Eastern Book Company, 2011).

52 PLD 1997 Lahore 38.

53 Id. at 60.

54 Albert V. Dicey, An Introduction to the Study of Law of Constitution 151 (10 ${ }^{\text {th }}$ ed., London and New York: Palgrave Macmillan, 1985).

55 Allahbukhsh Karimbukhsh Brohi, Fundamental Law of Pakistan (Karachi: Din Muhammadi Press, 1958).
} 
must be that the affairs of the Province cannot be run in accordance with the constitution, such satisfaction must be more than his personal opinion. ${ }^{56}$

Contrary to the case in India, in Pakistan presidential satisfaction is not subjective, rather it is objective, and such satisfaction must be based on some materials having a nexus with the purpose of Art. 234; the court can review the materials submitted before the President and satisfaction obtained out of that. In many ways the judgment of the Pakistani court was influenced by the judgment of the Indian Supreme Court in S.R. Bommai v. Union of India ${ }^{57}$ and particularly by the opinion of Justice P.B. Savant. In both judgments the Court made it clear that any violation of the Constitution will not be qualified as Constitutional Machinery Failure, whether permanent or temporary there has to be a constitutional deadlock and the imposition of Art. 234 has not be the only remedy left to break the deadlock, and whether the government has made an attempt or not to use the alternative remedies is also a subject of judicial scrutiny. ${ }^{58}$

\subsection{The Supreme Court of India: Redefining Constitutional Failure Emergency Model and Federalism in India 1950 to 2016}

In Rameshwar Prasad (VI) v. Union of India, ${ }^{59}$ the Supreme Court of India made it clear that the satisfaction of the President means the satisfaction of the Council of Ministers headed by the Prime Minister, which refers to India's belief in the parliamentary model rather than in the presidential exercise of emergency powers. Yet the post of Governor, who is a centre appointee, is critical and nowadays a matter of open favouritism towards the centre in India. Adding more complication, contrary to the current Pakistani constitutional provision the President may satisfy to proclaim emergency not only on the report of the Governor but also "otherwise." The word "otherwise" is of "wide amplitude,"

56 Supra note 52 , at 53-63.

$57 \quad$ AIR 1994 SC 1918.

58 The facts of Mian Manzoor Ahmad Wattoo v. Federation of Pakistan and Others is an interesting situation. In this case, the petitioner has pointed out that the Cabinet headed by the petitioner comprised of 225 Ministers and 224 Advisors out of whom 14 Ministers and 4 Advisors resigned. There is nothing on the record to show that these resignations resulted in impairment of the functions of the Government of Punjab in any manner. As already observed, resignations of Ministers are by itself not a ground for arriving at the conclusion that a situation had arisen where the affairs of the Province cannot be run in accordance with the Constitution. Even on factual plain therefore it is not shown that on account of resignations of the Ministers a Constitutional breakdown had occurred or that the functioning of the Government had been impaired. Thus the court pointed out that on the basis of mere resignations of some of the Ministers from the Provincial Cabinet the functionaries of two Governments could have come to the conclusion that the affairs of the Province cannot be run in accordance with the Constitution where there was no deadlock, impasse or breakdown of Constitutional machinery even temporary in the Province.

60 Arun Kumar Rai Chaudhary vs Union of India and Other, AIR 1992 All 1, para. 7. 
submitted by the Union Council of Ministers or the Union Home Ministry. Thus the satisfaction as well as the proclamation are in the hands of the Union Council of Ministers headed by the Prime Minister. More so, in Rameshwar Prasad (VI) v. Union of India ${ }^{61}$ the Supreme Court also established that the sufficiency or the correctness of the factual positions indicated in the Governor's report is not open to judicial review. The truth and correctness of the materials cannot be questioned by the court nor would the court go into the adequacy of the materials, and it would also not substitute its opinion for that of the President. Interference is called for only when there is a clear abuse or misuse of power, and the court will make allowance for the fact that the decision-making authority is the best judge of the situation. ${ }^{62}$

The Supreme Court of India has remained critical in determining "whether or not the situation has arisen that the government of the state cannot be carried out in accordance with the constitution."The Court has followed Rameshawar Prasad's principle of minimalist interference in respect of the particularities of the report rendered to the President for his satisfaction by the Governor, or otherwise, but the court can interfere when there is no connection reflecting Constitutional Machinery Failure as in the case of the suspension of a state government because the Chief Minister belongs to a particular caste or creed. ${ }^{63}$ State of Rajasthan v. Union of India ${ }^{64}$ has an interesting interpretation where Chief Justice Beg expressed his views that Indian federalism has "watered down" national integrity, but this view does not express the intent of the makers of the Constitution. The very fact that the framers enacted a federal constitution with a parliamentary form of government for the Union and the states shows that internal sovereignty was to be divided between the Union and the states. A literal construction of the broad general words of Art. 365 which would enable the Union Executive to cut at the root of the democratic parliamentary form of government in the states must be rejected in favour of the construction which would preserve that form of government. The exercise of this power must be limited to "a failure of constitutional machinery," that is, to preserving the parliamentary form of government from internal subversions, or from a deliberate deadlock created by a party or a group of parties, or from a deadlock arising from an indecisive electoral verdict which makes the carrying on of government practically impossible. ${ }^{65}$ Thus although it is difficult to list just when the power under Art. 356 can be exercised, it is possible, negatively, to state the situations in which the power cannot be exercised. On the basis of the facts of the Rajasthan case, Chief Justice Fazal Ali summarised that the satisfaction of the President is subjective, and if on these facts the President

61 Para. 96.

62 Rameshwar Prasad (VI) v. Union of India.

63 State of Rajasthan v. Union of India [Chandachud J., Beg J. and Fazal Ali J. (1977) 2 SCC 592: 1978(1) SCR 1].

64 Id. at para. 22.

65 Seervai 1991, at 3092, paras. 4, 5. 
was satisfied that action under Art. 356 was called for, and the legislative assemblies should be dissolved and fresh elections ordered, could such a conclusion be said to be unreasonable or malicious or based on extraneous consideration... The Court decided negatively.

The justiciability of the proclamation issued under Art. 356 was established by the $44^{\text {th }}$ Amendment, but it is still disputed as to its scope and application. The question was widely discussed by the panel of nine judges ${ }^{66}$ in multiple opinions in S.R. Bommai v. Union of India ${ }^{67}$ in which all of them agreed on the justiciability and judicial review of the proclamation whereas there was wide disagreement on the "extent of justiciability." Justices Ahmadi and K. Ramaswami were of the opinion that the advice rendered by the Council of Ministers is not immune from judicial review, while Justices Verma, Dayal, Sawant and Kuldeep were of the opinion of limited judicial review of the proclamation and advice so rendered is outside the purview of review. However, the majority viewed that any grounds upon which an executive determination is founded on "subjective satisfaction" can be questioned:

(1) if the proclamation was issued as per presidential satisfaction based on "no ground" at all [Justices Sawant, Pradhan, Jeevan Reddy and Aggrawal ${ }^{68}$;

(2) if the proclamation was based on consideration which is irrelevant and extraneous wholly [Justices Chandrachud, Bhagawati and Gupta in State of Rajasthan v. Union of India $\left.{ }^{60}\right]$, as in this case there will be no satisfaction. This point of view is reaffirmed in the S.R. Bommai case;

(3) if the proclamation is issued with "malice" it will also render satisfaction as "no satisfaction"; the proclamation can be challenged only on grounds of legal mala fide or high irrationality in exercise of the discretionary power to issue a proclamation [Justices Sawant, Pradhan, Jeevan Reddy and Agarwal ${ }^{70}$ ]. Thus, whenever the constitutionality of a proclamation is challenged it becomes necessary that the Union must produce the materials on which such action has been taken [Justices Sawant, Jeevan Reddy and Agarwal ${ }^{71}$;

(4) on the submission of the material which has rendered satisfaction, the court will determine whether the material is "relevant to the action," the court will not look into the "correctness of the material or its adequacy." But before calling upon the Union to produce the material the court must find a "strong prima facie" case that the proclamation is unconstitutional, and the court shall record the reason for ordering so.

66 Ahmadi J., Yogeshwar Dayal J., Verma J., Sawant J., Kuldeep J., K Ramaswami J., Jeevan Reddy J., Pradhan J., Aggrawal J.

67 (1994) 3 SCC 1.

${ }^{68}$ Id. paras. 187(1), 223 and 452(3).

69 State of Rajasthan v. Union of India, paras. 28 and 144.

70 (1994) 3 SCC 1, paras. 187(1) and 432.

${ }^{71}$ Id. paras. 2 and $452(2)$. 


\section{Lessons from Comparative Federalism with Reference to Constitutional Machinery Failure (Emergency) in India and Pakistan}

The Bommai judgment is a "watermark of judicial review" in respect of constitutional failure emergencies on both sides of the border; the Indian as well as the Pakistani Supreme Court has often quoted from the judgment. As observed by Soli J. Sorabjee, "[This] is a very salutary development and will go a long way in minimizing the onslaught on the State."72 On this basis the Indian Supreme Court has laid down several instances as permissible proclamation or as impermissible proclamation. These judgments have guided the judiciary in Pakistan too to restrict arbitrary actions of state machinery in the name of constitutional emergency.

Both Art. 234 of the Constitution of Pakistan and Art. 356 of the Constitution of India use the phrase "the government of a State cannot be carried on in accordance to this constitution". In the Bommai case, Justices Sawant and Kuldeep contemplated that there must be such a situation where the governance of the state is not possible by any alternatives. The word "cannot" emphatically describes a situation of impasse. If a remedy is available, then an Emergency Proclamation will not be used. This also justifies the aspiration of Dr Ambedkar, who played an instrumental role in shaping the Indian Constitution and particularly Art. 356, claiming it to be "a dead letter" and "would never be called into operation."73 This approach of the Bommai case is influenced by the judgment of the Pakistani Supreme Court in the case of Khawaja Ahmad Tariq Rahim v. Federation of Pakistan and Others, ${ }^{74}$ where Art. 58(2)(b) of that time was under review. As per Justice Shafiur Rahman for the majority opinion, "[S]ituations which can be remedied or do not create impasse, or do not disable or interfere with the governance of the State, cannot attract the situation of 'cannot' under the Constitution. The situation of 'cannot' is not an optional situation; it is the expression of 'the last situation' or 'the only option."' The majority opinion in Rahim went on to interpret "cannot" as the last resort, and the same opinion was referred to in Bommai to interpret Art. 356. Thus, post Bommai judgments in India and post Pir Sabir Shah, Niaz Ahmed Khan and Rahim judgments and the $18^{\text {th }}$ Constitutional Amendment 2010 in Pakistan, now courts on both sides of the border have clearly instructed that Constitutional Machinery Failure as it is titled in their respective chapters is an Emergency Provision and will be used as such, not on the basis of centralised adventure to usurp federalism, but always used as a "last resort."

Both in Rajasthan and in Bommai the main zone of disagreement was about the area and extent of judicial review and justiciability of Presidential Proclamation, but

72 Soli J. Sorabjee, Decision of the Supreme Court in S.R. Bommai v. Union of India: A Critique, (1994) 3 SCC (Jour) 1.

73 Constituent Assembly Debates: Official Report, Vol. IX, 170, 151, 131, 135, 148 and 177.

74 PLD 1992 SC 646. 
there is agreement on the existence of such broad power in a federal democratic setup, though claiming it under judicial review. Similarly, reference Pakistan's Supreme Court in Dwarkadas v. the State ${ }^{75}$ and Pir Sabir Shah v. Federation of Pakistan and Others, Justice Saeeduzzaman Siddiqui remarked:

Article 234 is necessary to preserve the system but the exercise of this power, which undoubtedly has far reaching and drastic consequences is not left by the framers of Constitution totally unbridled and uncontrolled... where it is discovered that the power has been exercised either outside the scope of Constitutional provision, or tainted with mala-fide or power has been exercised to achieve objects not contemplated in the Constitution, the Court has to scrutinize it.

But Indian courts have adopted the principle of limited judicial review of the proclamation, claiming the satisfaction of the President in India is to be reviewed subjectively only. The correctness or adequacy of the materials on which such satisfaction has been based is not subject to judicial scrutiny, the court will only examine "whether the materials are relevant for the action, if there is a strong prima facie case of its abuse." On the other hand, in Mian Manzoor Ahmad Wattoo v. Federation of Pakistan and Others the Lahore High Court mandated that Pakistan, unlike India, will not follow only the Subjectivity Test of the Proclamation but will judge the satisfaction of the President of Pakistan on the materials submitted before him/her objectively too. This judgment was the extension of the Pir Sabir Shah v. Federation of Pakistan and Others guideline which states the existence of a situation in which the government of the province cannot be run in accordance with the provisions of the Constitution cannot be treated subjectively. The satisfaction of the President in this regard must be based on objective conditions justifying the issuance of a proclamation under Art. 234.

In comparison, when Pakistan's judiciary had to affirm the justiciability of the proclamation under Art. 234 of the Pakistani Constitution 1972, the court used the rulings in Rajasthan and Bommai in Begum Nusrat Bhutto v. Chief of Army Staff, Niaz Ahmed Khan v. Province of Sindh and Pir Sabir Shah v. Federation of Pakistan and Others. Courts on both sides of the border wanted to establish the legitimacy of judicial review with caution and balance as to prevail between the Executive's use of power in an emergency and the arbitrary use of the same power to destroy the federalism which has been the centre theme of the constitution of both countries. Both in India and in Pakistan, Constitutional Machinery Failure Emergency has taken its distinct route and gone through major changes. Both countries have made this provision to subvert provincial autonomy.

\footnotetext{
75 PLD 1957 SC (Pakistan) 72.
} 


\section{Reasons and Suggestions}

India and Pakistan both claim to be federal, both believe in their claimed federalism; contrary to that, both countries have watered down the elements of federalism for the aspiration of national integration and centralised co-ordination. The constitutions of India and Pakistan have shown their fundamental belief in Union of States and Federal Islamic Republic, respectively, likewise their struggles for freedom, led by the Indian National Congress and the Muslim League, respectively. This aspiration has not gained the desired prominence in their respective constitutions, and it was an intentional and deliberate act of the constitution-making bodies of the two States to keep federalism in words and titles as an adjective, but not in spirit. Constitutions both in India and in Pakistan have been guided by their colonial source, GolA 1935, which was to keep the provinces within the grip of the centre. The constitution-building process in India and Pakistan deliberately denied changing the colonial instrument of Constitutional Machinery Failure Emergency and conceived it to remain "a dead letter" and that it "shall not be used." In this situation, the constitution and polity have been guided not only by their colonial source but also by the colonial mindset to keep shared power only in words and not in actions, to keep provincial units within the overpowering supervision of the centre and yet claiming the country to be "perfectly uniquely federal."The Emergency Proclamation on the basis of Constitutional Machinery Failure has been instrumental in ensuring the centre's dominance over the provinces in India and Pakistan, as this power, as in colonial times, remains in the hands of the centre, unchecked, uncontrolled and more often than not even uncared for by jurists, or researchers as a matter for comparative and debated discussions. Abrogation of the Constitution of 1956 and 1962 in Pakistan and imposition of Constitutional Machinery Failure Emergency Proclamations more than one hundred times in India are reflective of abuse of the process in favour of the centre, both in India and in Pakistan. The Constitutional Machinery Failure Emergency Model in India and Pakistan has gone through progressive changes via judicial interpretations in India by the Rajasthan and Bommai cases and the $18^{\text {th }}$ Constitutional Amendment 2010 in Pakistan. This progressive outlook has been influenced by internal misuse of the provision and also by the developments on the other side of the border. The Begum Bhutto judgment influenced the approach of the judges in Bommai, and Bommai's mandate of judicial reviewability of the proclamation gave strength to the judges in Pakistan to maintain its strong impartial and democratic outlook regarding the reviewability of the Pakistani Emergency Proclamation in the Pir Sabir Shah and Niaz Ahmed Khan rulings. Post $18^{\text {th }}$ Amendment in Pakistan, there is scope for positive and progressive deliberations in respect of shared power and federalism in Pakistan, which are under scrutiny and research.

The aim of this article is to motivate and provide the base for such comparative researches in India and Pakistan as well as in South Asia on the Provincial Emergency Model. The words of Professor Upendra Baxi, referring to the struggle of the Pakistani 
Supreme Court (PSC) has been the guiding force of this article:"The story of baptism by fire of the PSC also makes the community of Indian lawpersons a little more uncomfortable in their mimetic modes of doing jurisprudence, which truly ignores the developments next door, in the search for wisdom across the seven seas."176

\section{References}

Adeney K.S. Federal Formation and Consociational Stablisation: The Politics of National Identity Articulation and Ethnic Regulation in India and Pakistan, PhD thesis, The London School of Economics and Political Science (LSE) (2003) (May 10, 2017), available at http://etheses.lse.ac.uk/428/.

Agamben G. State of Expression (Kelvin Attell (trans.), Chicago: University of Chicago Press, 2005).

Austin G. The Indian Constitution: Cornerstone of the Nation (Oxford: Clarendon Press, 1966).

Baxi U. Constitutional Interpretation and State Formative Practices in Pakistan: A Preliminary Exploration in Comparative Constitutional Law: Festschrift in honour of Professor P.K. Tripathi (M.P. Singh (ed.), $2^{\text {nd }}$ ed., Lucknow: Eastern Book Company, 2011).

Benton L. Empires of Exception: History, Laws and Problems of Imperial Sovereignty, 6 Quaderni di Relazioni Internazionali (2007).

Brohi A.K. Fundamental Law of Pakistan (Karachi: Din Muhammadi Press, 1958).

Feldman H. Constitution of Pakistan (Karachi: Oxford University Press, 1956).

Ferejohn J. \& Pasquino P. The Law of Exception: A Typology of Emergency Powers, 2(2) International Journal of Constitutional Law (2004).

Hussain N. The Jurisprudence of Emergency: Colonialism and the Rule of Law (Ann Arbor: The University of Michigan Press, 2003).

Jalal A. Democracy and Authoritarianism in South Asia: A Comparative and Historical Perspective (Lahore: Pakistan Sang-e-Meel Publications, 1995).

Jalal A. The Struggle for Pakistan: A Muslim Homeland and Global Politics (Cambridge: Belknap Press of Harvard University Press, 2014).

Jennings I. Constitutional Problems in Pakistan (Cambridge: Cambridge University Press, 1957).

Kostal R.W. A Jurisprudence of Power: Victorian Empire and the Rule of Law (Oxford and New York: Oxford University Press, 2008).

Maluka Z.A. The Myth of Constitutionalism in Pakistan (Karachi and New York: Oxford University Press, 1995).

McGarry J. \& O'Leary B. Introduction: The Macro-Political Regulation of Ethnic Conflict in The Politics of Ethnic Conflict Regulation: Case Studies of Protracted Ethnic Conflicts (J. McGarry \& B. O'Leary (eds.), London and New York: Routledge, 1993).

76 Baxi 2011, at 201. 
Mill J.S. A System of Logic Ratiocinative and Inductive: Being a Connected View of the Principles of Evidence and the Method of Scientific Investigation. Vol. 1 ( $9^{\text {th }}$ ed., London: Longmans, Green, Reader, and Dyer, 1875).

Omar I. Emergency Powers and Courts in India and Pakistan (Leiden, Boston: Martinus Nijhoff Publishers, 2002).

Rajagopalan S. State and Notion of South Asia (Boulder: Lynne Rienner Publishers, 2001).

Schmitt C. Political Theology: Four Chapters on the Concept of Sovereignty (George Schwab (trans.), Chicago: University of Chicago Press, 1965).

Seervai H.M. Constitutional Law of India ( $4^{\text {th }}$ ed., New Delhi: Universal Publication House, 1991).

Shah S.M.H. Federalism in Pakistan: Theory and Practice (Islamabad: Quaid-i-Azam University, 1994).

Sharma J.P. Federal Systems in India and Pakistan: A Comparative Perspective (Jaipur: Printwell, 1987).

Shiva Rao B. The Framing of Indian Constitution: A Study (New Delhi: Indian Institute of Administration, 1968).

Sorabjee S.J. Decision of the Supreme Court in S.R. Bommai v. Union of India: A Critique, (1994) 3 SCC (Jour) 1.

Talbot I. Inventing the Nation: India and Pakistan (London: Hodder Arnold, 2000).

Vile M.J.C. Federalism and Confederation: The Experience of the United States and the British Commonwealth in Political Cooperation in Divided Societies (P. Rea (ed.), Dublin: Gill and Macmillan, 1982).

Waseem M. Federalism in Pakistan (August 2010) (May 10, 2017), available at http://www.forumfed.org/pubs/Waseem-Fed-Overview.pdf.

Watts R.L. Contemporary Views on Federalism in Evaluating Federal Systems (B. De Villiers (ed.), Cape Town: Juta, 1994).

Watts R.L. Federalism, Federal Political Systems and Federations, 1(1) Annual Review of Political Science (1998).

Wheare K.C. Federal Government (4 ${ }^{\text {th }}$ ed., London: Oxford University Press, 1963).

\section{Information about the author}

Panch Rishi Dev Sharma (Lucknow, India) - Assistant Professor, Department of Law, Public University of Lucknow (Sitapur Rd, Sultanpur Village, Jankipuram Extension, Lucknow, Uttar Pradesh, 226021, India; e-mail: panchrishidevsharma@ gmail.com). 